\title{
Separation of Sublethal and Lethal Effects of Polymorphonuclear Leukocytes on Escherichia coli
}

Brian A. Mannion, Jerrold Weiss, and Peter Elsbach

Departments of Microbiology and Medicine, New York University School of Medicine, New York 10016

\begin{abstract}
Escherichia coli ingested by PMN promptly stop growing and form no colonies in nutrient agar, but metabolize near normally for up to several hours. The bactericidal/permeability increasing protein (BPI) of PMN also inhibits $E$. coli growth without initial metabolic impairment. We recently showed that BPItreated $E$. coli, although unable to grow in normal nutrient agar, can form colonies in this medium plus $0.1 \%$ BSA, as long as their metabolism is maintained, indicating that biochemical impairment is a better indicator of death than growth arrest (1990. J. Clin. Invest. 85:853-860). We have now reexamined the fate of ingested $E$. coli. Rabbit PMN ingest $>85 \%$ of several rough $E$. coli strains in $15 \mathrm{~min}$, but $>80 \%$ of these bacteria, while unable to form colonies in conventional agar, grow normally on agar plus $0.1 \%$ BSA. Thus, the PMN under these conditions promptly stop growth of ingested $E$. coli without killing. Adding nonlethal concentrations of normal human serum (NHS) before, but not after ingestion, accelerates killing and, in parallel, loss of bacterial metabolism ( $t_{1 / 2}$ $<0.5 \mathrm{~h}$ vs. $>3 \mathrm{~h}$, respectively, with and without NHS). The rapid killing of both rough and smooth $E$. coli pretreated with NHS is lost after C7 depletion (C7-D) and restored when $C 7$ is replenished. Similar results are obtained with human PMN. In contrast, ingested Staphylococcus epidermidis, opsonized with either NHS or C7-D serum rapidly stop metabolizing and do not form colonies in nutrient agar with or without BSA. Respiratory burst activity is the same during ingestion of $E$. coli (with or without NHS) and S. epidermidis. Killing of $E$. coli J5 (however, not of 0111-B4) by BPI is also accelerated by pretreatment with NHS but not C7-D human serum. These findings indicate that late complement components are needed for efficient killing of both rough and smooth $E$. coli by PMN, and that BPI is the principal intracellular agent acting on ingested rough $E$. coli. (J. Clin. Invest. 1990. 86:631-641.) Key words: bactericidal/permeability increasing protein - complement • growth inhibition • serum albumin
\end{abstract}

\section{Introduction}

A paradox in the apparent killing of gram-negative bacteria by both intact PMN and the purified bactericidal/permeability

Address correspondence to Dr. Peter Elsbach, Department of Medicine, New York University Medical Center, 550 First Avenue, New York, NY 10016.

Received for publication 28 December 1989 and in revised form 9 April 1990.

J. Clin. Invest.

(c) The American Society for Clinical Investigation, Inc.

0021-9738/90/08/0631/11 \$2.00

Volume 86, August 1990, 631-641 increasing protein $(\mathrm{BPI})^{1}(1,2)$, located in the primary granules of both human and rabbit PMN (3), is that prompt growth arrest, as determined by direct counting in a bacterial counting chamber or by colony formation in nutrient agar plates, is not accompanied by appreciable structural and functional damage for up to several hours $(1,2,4-6)$. We have recently reported that the level of metabolic activity by Escherichia coli treated with BPI correlates closely with the number of bacteria that are capable of resuming growth in the presence of $0.1 \%$ BSA, revealing that BPI initially produces only sublethal effects, and thus lack of colony formation, as determined by generally accepted assays of bacterial viability, need not reflect bacterial death (7).

Since we have shown before that the fates of $E$. coli exposed to purified BPI or ingested by intact PMN are nearly indistinguishable with respect to alterations in the outer envelope and lack of initial biochemical and structural damage (1, 2, 4-6), we explored in this study the possibility that $E$. coli, although incapable of growing under the conventional culture conditions after ingestion by PMN, may in fact also not be dead. The results show that indeed PMN are unexpectedly inefficient killers of both rough and smooth strains of $E$. coli, and that pretreatment of these gram-negative bacteria with nonlethal concentrations of normal human serum (NHS), but not C7-depleted (C7-D) serum, dramatically enhances the efficiency of killing of $E$. coli by the PMN.

\section{Methods}

Preparation of PMN. Rabbit PMN were obtained from sterile peritoneal exudates elicited in New Zealand white rabbits by injection of glycogen in physiological saline as previously described (8). Cells were collected 12-14 h later. Human PMN were collected as described (9) from heparinized venous blood obtained after informed consent from healthy volunteers. The cells were sedimented at $50 \mathrm{~g}$ for $10 \mathrm{~min}$, washed twice with HBSS without phenol red (Microbiological Associates, Inc., Walkersville, MD), and resuspended in the same medium at a concentration of $1 \times 10^{8} \mathrm{PMN} / \mathrm{ml}$.

Radiolabeling of human C7. $200 \mu \mathrm{g}$ purified human C7 (Calbiochem-Behring Corp., San Diego, CA) was dialyzed against a 1,000X vol of $40 \mathrm{mM} \mathrm{Na} 2 \mathrm{HPO}_{4} / \mathrm{NaH}_{2} \mathrm{PO}_{4}$ buffer, $\mathrm{pH} 7.4$, and added to a tube precoated with $75 \mu \mathrm{g}$ iodogen (Pierce Chemical Co., Rockford, IL) (10). $1 \mu$ l sodium iodide ( ${ }^{125} \mathrm{I}, 482 \mu \mathrm{Ci}, 17 \mathrm{Ci} / \mathrm{mg}$; New England Nuclear, Boston, MA) was added, followed after $15 \mathrm{~min}$ on ice by 1:20 vol of $2 \mathrm{M}$ potassium iodide, and the mixture was passed through a Sephadex G-25 column (Pharmacia Fine Chemicals, Piscataway, NJ) preequilibrated with $40 \mathrm{mM} \mathrm{Na} \mathrm{HPO}_{4} / \mathrm{NaH}_{2} \mathrm{PO}_{4}$ buffer, $\mathrm{pH}$ 7.4.

Preparation of human serum. Venous blood was collected from healthy volunteers after informed consent. The serum was collected after clot formation, centrifuged at $10,000 \mathrm{~g}$ for $20 \mathrm{~min}$ to remove any debris, and stored at $-70^{\circ} \mathrm{C}$. C7-D serum was prepared by immunoaf-

1. Abbreviations used in this paper: BPI, bactericidal/permeability increasing protein; C7-D, complement component 7-depleted; NHS, normal human serum. 
finity chromatography of freshly prepared human serum on Affi-Gel 10 (Bio-Rad Laboratories, Richmond, CA) containing covalently coupled goat anti-human C7 IgG (Calbiochem-Behring Corp.), prepared according to the instructions of the manufacturer. Recovery of unbound human serum protein ( $>95 \%$ ) was followed by measurement of A $_{280}$ using a spectrophotometer (model DU-7; Beckman Instruments, Inc., Palo Alto, CA). Depletion of $\mathrm{C} 7$ was monitored by two independent methods: $(a)$ by following the disappearance of ${ }^{125} \mathrm{I}$-labeled $\mathrm{C} 7$ during the chromatographic procedure, and $(b)$ by following the loss of the ability of the serum to kill a rough strain of $E$. coli (J5), and the restoration of the bactericidal activity toward the level of untreated serum after supplementing the depleted serum with purified $\mathrm{C} 7$ to a final concentration of $50 \mu \mathrm{g} / \mathrm{ml}$.

Purification of BPI. Rabbit BPI was purified as previously described (2) and stored in $50 \mathrm{mM}$ sodium acetate/acetic acid buffer, pH 4.0.

Bacterial strains and growth conditions. The rough E. coli strain $\mathrm{J} 5$, its parent smooth strain O111:B4, and the smooth strain ML-35 were grown in triethanolamine-buffered $(\mathrm{pH}$ 7.7-7.9) minimal salts me-

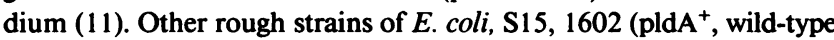
strain), 1303, (pldA ${ }^{-}$, lacking the principal envelope phospholipase), and 1303 pPI232 (pldA ${ }^{+++}$), a phospholipase-rich strain containing the wild-type pldA gene in a multicopy plasmid (12) were grown in physiologic saline supplemented with $0.8 \%$ (wt/vol) nutrient broth (Difco Laboratories Inc., Detroit, MI). Staphylococcus epidermidis (\#14990; American Type Culture Collection, Rockville, MD) was grown in trypticase soy broth (BBL Microbiology Systems, Cockeysville, MD). Growth media were supplemented with $50 \mu \mathrm{g} / \mathrm{ml}$ chloramphenicol (Parke-Davis, Morris Plains, NJ) for growth of E. coli 1303pPI232 to select for bacteria containing the plasmid encoding the pldA gene product and chloramphenicol resistance. Stationary phase overnight cultures were transferred to fresh medium (diluted 1:20) and grown to mid-to-late logarithmic phase (about $3 \mathrm{~h}$ ) at $37^{\circ} \mathrm{C}$. Where indicated, the growth medium was supplemented with $1 \mu \mathrm{Ci} / \mathrm{ml}\left[1-{ }^{14} \mathrm{C}\right]$ oleic acid ( $57 \mathrm{mCi} / \mathrm{mmol}$; New England Nuclear), or $5 \mu \mathrm{Ci} / \mathrm{ml}$ [methyl- ${ }^{3} \mathrm{H}$ ]thymidine $(20 \mathrm{Ci} / \mathrm{mmol}$; New England Nuclear) plus $2 \mathrm{mM}$ uridine (Sigma Chemical Co., St. Louis, MO) to label bacterial phospholipids or DNA, respectively, during growth of the bacteria in subculture. Bacterial concentrations were determined by measuring the $\mathrm{OD}_{550}$ in a spectrophotometer (Junior model, Coleman Instruments, Inc., Maywood, IL). The bacteria were sedimented in a clinical centrifuge for 12 min and resuspended to a final concentration of $1 \times 10^{9}$ cells $/ \mathrm{ml}$ in sterile isotonic $(0.9 \%)$ saline. In the case of radiolabeled bacteria, the cell pellet was resuspended in fresh growth medium without added radiolabeled precursors and further incubated for $30 \mathrm{~min}$ at $37^{\circ} \mathrm{C}$ before resuspension in isotonic saline. In the case of phospholipidlabeled bacteria, the bacteria were washed once with $1 \%(\mathrm{wt} / \mathrm{vol}) \mathrm{BSA}$ at the end of the chase period to remove any unesterified radiolabeled precursors.

Incubation of E. coli with BPI. Purified rabbit BPI (2-4 $\mu \mathrm{g})$ was added to bacteria $\left(1 \times 10^{7}\right)$ in $0.25 \mathrm{ml}$ of physiologic saline that also contained $10 \%$ (vol/vol) HBSS, $40 \mathrm{mM}$ Tris/ $\mathrm{HCl}, \mathrm{pH} 7.5$, and $0.1 \%$ (wt/vol) vitamin-free casamino acids (Difco Laboratories) and incubated at $37^{\circ} \mathrm{C}$. Where indicated, the bacteria were first incubated with the indicated preparation of fresh NHS $\left(30 \mathrm{~min}\right.$ at $\left.37^{\circ} \mathrm{C}\right)$, centrifuged at $13,000 \mathrm{~g}$ for $1 \mathrm{~min}$ to remove unbound serum constituents, and resuspended in the same medium before adding BPI.

Incubation of bacteria with PMN. Typical incubation mixtures contained bacteria $\left(5 \times 10^{7}\right.$ in $50 \mu \mathrm{l}$ of sterile isotonic saline) and PMN $\left(5 \times 10^{6}\right.$ in $50 \mu$ l of HBSS), added sequentially to $150 \mu$ l sterile isotonic saline containing $10 \%$ HBSS buffered with either $20 \mathrm{mM}$ Hepes, $\mathrm{pH}$ $7.3,20 \mathrm{mM} \mathrm{Na} \mathrm{HPO}_{4} / \mathrm{NaH}_{2} \mathrm{PO}_{4}, \mathrm{pH} 7.3$, or $20 \mathrm{mM}$ bicarbonate buffer, $\mathrm{pH} 7.3$, as indicated, and were incubated at $37^{\circ} \mathrm{C}$ with shaking. Where indicated, human serum was also added at the given concentration after the bacteria but before the PMN. In some experiments, either the bacteria or the PMN were first exposed to serum (30 min at $37^{\circ} \mathrm{C}$ ), followed by removal of the serum by centrifugation before incubation of bacteria plus PMN. At the indicated time points the incubation was stopped by adding an equal volume of ice-cold isotonic saline to each sample.

Measurement of ingestion of bacteria by PMN. E. coli prelabeled with either $\left[{ }^{3} \mathrm{H}\right]$ thymidine or $\left[{ }^{14} \mathrm{C}\right]$ oleic acid were incubated at $37^{\circ} \mathrm{C}$ with PMN in the standard incubation mixtures. After interruption of phagocytosis at various times by adding ice-cold physiologic saline, the samples were spun at $100 \mathrm{~g}$ for $7 \mathrm{~min}$ to separate cell-associated and extracellular bacteria, and the cell pellet was washed 2 times with $1 \%$ BSA/HBSS to remove trapped and loosely adherent bacteria. In the case of $\left[{ }^{14} \mathrm{C}\right]$ leic acid-labeled bacteria, the supernatant was then subjected to centrifugation at $13,000 \mathrm{~g}$ for $5 \mathrm{~min}$ to separate the uningested bacteria from the released products of phospholipid hydrolysis complexed by the added BSA (13). The distribution of the radiolabeled bacteria was determined by measuring aliquots of the recovered supernatant, the resuspended bacterial pellet, and the resuspended PMN cell pellet by liquid scintillation counting (5). There was no detectable conversion of radiolabeled material from TCA-precipitable to TCAsoluble form during the course of the incubation. Uptake (ingestion) is expressed as the percent of the total recovered radioactivity that is associated with the PMN cell pellet in the case of $\left[{ }^{3} \mathrm{H}\right]$ thymidine-labeled bacteria and of the sum of the radioactivity in cell pellet plus supernatant $(<5 \%$ of total radioactivity was present in the supernatant during the first $30 \mathrm{~min}$ ) fractions in the case of $\left[{ }^{14} \mathrm{C}\right]$ oleic acid-labeled bacteria. Recovery of total added radioactivity was always $>90 \%$.

Assay of bacterial viability. After the indicated incubation at $37^{\circ} \mathrm{C}$, samples were subjected to a brief (8-s pulse on ice) sonication using a micro-ultrasonic cell disrupter (Kontes Co., Vineland, NJ) at 75\% of full strength. Aliquots of the sonicated suspension were serially diluted 40,000 -fold in sterile isotonic saline containing $4 \mathrm{mM} \mathrm{MgCl}_{2}$ and 400 $\mu \mathrm{g} / \mathrm{ml}$ BSA (United States Biochemical Corp., Cleveland, OH). A 25- $\mu \mathrm{l}$ aliquot of the diluted sample was transferred to $5 \mathrm{ml}$ of $1.3 \%$ (wt/vol) molten $\left(47^{\circ} \mathrm{C}\right.$ ) Bacto-agar (Difco Laboratories) containing $0.8 \%$ (wt/ vol) nutrient broth and $0.5 \%(\mathrm{wt} / \mathrm{vol}) \mathrm{NaCl}$ and poured into a Petri dish. Where indicated, the molten agar was supplemented with 1 $\mathrm{mg} / \mathrm{ml}$ BSA. The agar was allowed to solidify at room temperature, and bacterial viability was measured as the number of colonies formed after incubation at $37^{\circ} \mathrm{C}$ for $18-24 \mathrm{~h}$.

Measurement of bacterial protein synthesis. Bacteria were incubated with PMN as described above except that the medium was supplemented with $0.5 \mathrm{mM}$ cycloheximide to block protein synthesis by the PMN. At the indicated time points, ${ }^{14} \mathrm{C}$-L-amino acids $(1 \mu \mathrm{Ci} / \mathrm{ml}$ final concentration) were added, and the mixtures were incubated an additional $15 \mathrm{~min}$. Reactions were terminated by the addition of icecold TCA to a final concentration of $10 \%$, and the tubes were left on ice for $30 \mathrm{~min}$. TCA-precipitable radioactive material was collected by filtration through a $0.45-\mu \mathrm{m}$ HAWP membrane (Millipore/Continental Water Systems, Bedford, MA), washed three times with $1 \mathrm{ml} \mathrm{10 \%}$ ice-cold TCA, and measured by liquid scintillation counting (5). Protein synthesis is expressed as a percentage of the total amino acid incorporation into TCA-precipitable material by untreated $E$. coli during the same 15 -min period.

Measurement of hexose monophosphate shunt activity. For measurement of hexose monophosphate shunt activity of PMN during phagocytosis of bacteria, the same incubation procedure was carried out as above $\left(1 \times 10^{7} \mathrm{PMN}\right.$ and $1 \times 10^{8}$ bacteria in a total volume of $0.5 \mathrm{ml}$ ) except that $15-\mathrm{ml}$ polypropylene tubes sealed with a rubber stopper were used, and the suspension was supplemented with $5 \mathrm{mM}$ $\mathrm{KCN}$ to block bacterial respiration and $0.03 \mu \mathrm{Ci}$ of $\left[1-{ }^{14} \mathrm{C}\right] \mathrm{D}$-glucose (45 mCi/mol; New England Nuclear). Incubations were started after addition of bacteria to the PMN, and hexose monophosphate shunt activity was measured as conversion of $\left[1-{ }^{14} \mathrm{C}\right]$ glucose to ${ }^{14} \mathrm{CO}_{2}(14)$. Evolved ${ }^{14} \mathrm{CO}_{2}$ was collected in polyethylene cups suspended from rubber stoppers. At the end of the incubation, the reaction was stopped by injecting $0.2 \mathrm{ml}$ of $10 \mathrm{~N} \mathrm{H}_{2} \mathrm{SO}_{4}$ through the rubber stopper with a 21-gauge needle. After $15 \mathrm{~min}$, hydroxide of hyamine $(0.3 \mathrm{ml})$ (Packard Instrument Co., Inc. Downers Grove, IL) was added to the collection cups, and incubation at $37^{\circ} \mathrm{C}$ was continued for an additional 60 min. At this time the cups were removed, placed in counting vials, and 
vigorously shaken with $9 \mathrm{ml}$ of toluene-BBOT (2,5-bis-2-(5-tert-butylbenzoxazolyl)-thiophene; (Packard Instrument Co., Inc.) scintillation mixture and immediately counted as described (5).

Preparation of samples for transmission electron microscopy. For electron microscopy, the incubation of PMN and bacteria was terminated by the addition of ice-cold $0.7 \%$ glutaraldehyde in Kellenberger's veronal acetate buffer (15), pH 6.1, and the samples were incubated an additional 30 min on ice. The PMN were then sedimented by centrifugation $(100 \mathrm{~g} / 1 \mathrm{~min})$ and the pellets were resuspended in $2.5 \%$ glutaraldehyde in veronal acetate buffer and incubated for $2 \mathrm{~h}$ at $10^{\circ} \mathrm{C}$. The cells were then washed three times with the veronal acetate buffer and postfixed with $1 \%$ osmium tetroxide in the same buffer for $16 \mathrm{~h}$ at $10^{\circ} \mathrm{C}$. Cells were stained with uranyl magnesium acetate $(0.5 \%)$ for $1 \mathrm{~h}$ at $20^{\circ} \mathrm{C}$ and embedded in $1 \%$ noble agar. The agar-embedded blocks were dehydrated in the presence of increasing concentrations of ethyl alcohol and replaced with propylene oxide as a last step. Specimens were infiltrated and embedded in a low viscosity epoxy resin (Polysciences, Inc., Warrington, PA) and thin sections were made with an ultratome (LKB Instruments, Inc., Gaithersburg, MD) using a diamond knife. Sections were mounted on Formvar-carbon-coated grids and double-stained with uranyl acetate and lead citrate by the method of Frasca and Parks (16). Stained samples were viewed in an Elmiskop 1A electron microscope (Siemens Corp., Iselin, NJ), and images were recorded on film 4489 (Eastman Kodak Co., Rochester, NY).

\section{Results}

Prolonged intracellular survival of E. coli J5 after ingestion by rabbit PMN. As we have shown before in studies of the fate, during phagocytosis, of other rough strains of $E$. coli and Salmonella typhimurium, incubation of $E$. coli $\mathrm{J} 5$ with rabbit PMN causes damage to the outer envelope (4-6) and rapid inhibition of colony formation on nutrient agar, yet the bacteria continue to incorporate ${ }^{14} \mathrm{C}$-amino acids into acid-precipitable material at nearly the same rate as untreated bacteria (Fig. 1, left). When the bacteria are plated in nutrient agar supplemented with $0.1 \%$ BSA instead of normal nutrient agar, nearly all the added $E$. coli now are able to form colonies, demonstrating that these bacteria actually have not been killed. Bacterial colony-forming ability on BSA-supplemented, but not unsupplemented, nutrient agar and incorporation of radiolabeled amino acids are preserved for several hours (Fig. 1, left), indicating that the bacteria, although in- jured $(4,5)$ and growth inhibited, are in fact metabolically active and viable. Identical results are obtained in Hepes, $\mathrm{NaH}_{2} \mathrm{PO}_{4} / \mathrm{Na}_{2} \mathrm{HPO}_{4}$, or bicarbonate-buffered cell suspensions (not shown).

Although demonstration of bacterial colony formation in BSA-supplemented nutrient agar required lysis of the PMN, the surprising survival of $E$. coli during prolonged incubation with PMN prompted us to seek further verification that these bacteria had indeed been ingested. Separation of PMN-associated from extracellular (noningested) bacteria by low speed centrifugation showed that $>85 \%$ of the viable bacteria were PMN associated (Fig. 1, right). Maximum bacterial uptake was achieved within $15 \mathrm{~min}$ of incubation, and the bacteria remained cell associated throughout 3-h incubations. Examination of thin sections of PMN pellets by transmission electron microscopy confirmed that PMN-associated $E$. coli were intracellular and also demonstrated the ultrastructural integrity of these bacteria, even after prolonged intraphagosome residence (Fig. 2).

Effect of bacterial load on intracellular survival of $E$. coli. To determine whether the ability of $E$. coli to survive after ingestion by PMN depends on the mass of bacteria ingested, the number of $E$. coli added to the PMN was varied over a 100-fold range, from 0.5 to 50 bacteria per PMN. Ingestion and nearly complete inhibition of growth in nutrient agar were equally efficient ( $>85 \%$ within $15 \mathrm{~min}$ ) at all ratios. After 30-min incubation at all ratios tested, nearly all the added bacteria had been ingested by the PMN and did not form colonies in nutrient agar. At this time, at least $75 \%$ of the bacteria could still form colonies in BSA-supplemented nutrient agar, independent of the bacterial load (Fig. 3). However, at later time points a slow decrease in colony formation in BSA-supplemented nutrient agar was evident at low bacterial loads $\left(t_{1 / 2} \sim 70\right.$ and $120 \mathrm{~min}$ at 0.5 and $2 \mathrm{E}$. coli/PMN, respectively), but not at bacteria/PMN ratios $\geq 10$ (Fig. 1, left, and Fig. 3).

Fate of other E. coli strains after ingestion by rabbit PMN. To determine whether the prolonged intracellular survival of ingested, sublethally injured $E$. coli $\mathrm{J} 5$ is representative of the fate of the $E$. coli species in general, we examined the effects of rabbit PMN on several other strains of $E$. coli (all at a bacte-

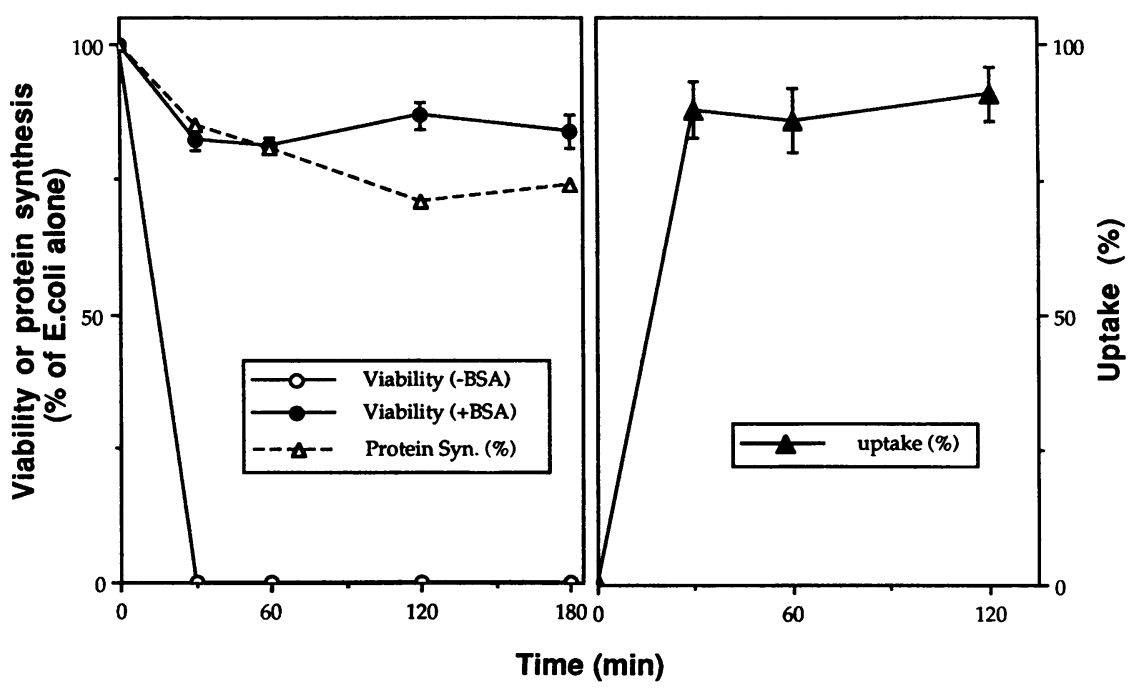

Figure 1. Rescue by BSA of $E$. coli ingested by rabbit PMN. $\left[{ }^{3} \mathrm{H}\right]$ Thymidine-labeled $E$. coli J5 $\left(5 \times 10^{7}\right.$ in $250 \mu$ l) were incubated with rabbit PMN $\left(5 \times 10^{6}\right)$ at $37^{\circ} \mathrm{C}$ in the standard incubation medium. At the indicated time points after adding PMN, viability (left) with (solid circles) or without (open circles) BSA (1 $\mathrm{mg} / \mathrm{ml}$ ) in the growth medium, protein synthesis (dotted line), and bacterial uptake (right) were measured as described in Methods. The data shown represent the mean \pm SEM of at least four experiments except for protein synthesis, which represents the mean of two closely similar experiments. In the absence of PMN, bacterial viability was $>90 \%$, and bacterial ${ }^{14} \mathrm{C}$-amino acid incorporation into acidprecipitable material was $\sim 12,000 \mathrm{cpm}$ in 15 $\min$. 


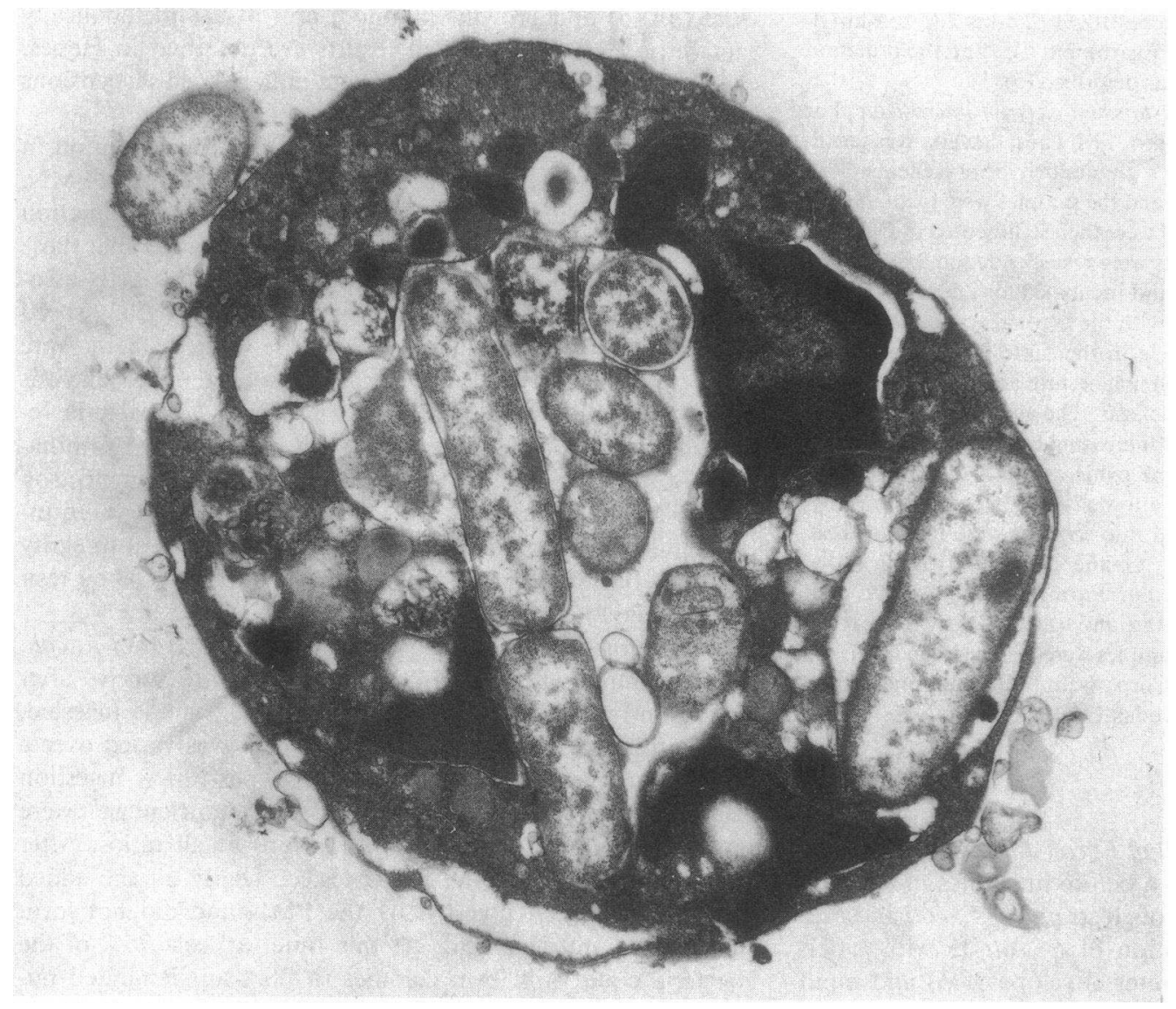

Figure 2. Transmission electron microscopy of rabbit PMN after incubation with E. coli 1303 for $60 \mathrm{~min}$. $\times 16,000$.
ria/PMN ratio of 10:1). The findings with five other rough strains tested, exemplified by $E$. coli S15, 1303, and 1602 (Fig. $4, a-c$ ), were virtually identical to those shown for $E$. coli $\mathrm{J} 5$; i.e., phagocytosis caused almost immediate arrest of colony formation in nutrient agar, but the bacteria continued nearnormal protein synthesis and colony formation in BSA-supplemented nutrient agar for at least $2 \mathrm{~h}$. The one exception was $E$. coli 1303 pPI232, a derivative of $E$. coli 1303 that carries a high copy plasmid that bears the wild-type gene (pldA) for the outer membrane phospholipase $A$, resulting in a 20 -fold increase in bacterial phospholipase A content (12) and a doubling of bacterial phospholipid degradation during phagocytosis (13). After ingestion, this strain showed a much more rapid $\left(t_{1 / 2} \sim 30 \mathrm{~min}\right)$ loss of colony-forming ability in BSA-containing nutrient agar and a parallel inhibition of protein biosynthesis (Fig. $4 d$ ). This confirms our recent study showing a role of bacterial and host phospholipases in the rate of destruction of ingested $E$. coli (13).

In contrast to the ability of most rough strains of $E$. coli to survive for extended periods of time within PMN, neither of the two smooth strains of $E$. coli examined survived intracellularly. Ingested $E$. coli ML-35 and O111:B4 promptly lost their ability to form colonies in nutrient agar both in the absence and presence of BSA, with a coincident inhibition of bacterial protein synthesis (Fig. $4, e$ and $f$ ). The more rapid killing of ML-35 is attributable to faster uptake of this strain.

Role of serum in intracellular killing of $E$. coli by rabbit $P M N$. The much more rapid killing, after ingestion, of smooth $E$. coli compared with rough $E$. coli was unexpected because smooth strains are generally more resistant to many of the elements of the host defense apparatus $(17,18)$. The more phagocytosis-resistant smooth $E$. coli, but not rough $E$. coli, require serum for ingestion by rabbit $\operatorname{PMN}(18,19)$. Serum might, therefore, play a role in the more efficient killing of smooth $E$. coli. Indeed, addition of nonlethal amounts (Table I) of NHS to suspensions of PMN and either of two rough strains, E. coli 1303 (Fig. 5) or E. coli J5 (Table II) markedly accelerated killing (i.e., inhibition of colony formation in BSA-supplemented nutrient agar). This effect of serum was dose dependent and followed uptake (Fig. 5), indicating that the lethal damage occurred intracellularly. Pretreatment of the bacteria but not the PMN was needed for the serum effect; thus, washed $E$. coli that had been pretreated with serum were rapidly killed after ingestion by PMN, whereas untreated $E$. coli still exhibited prolonged intracellular survival after phagocytosis by serum-pretreated and washed PMN (Table II). Further, the ingested $E$. coli remained viable when serum was added to the PMN after phagocytosis was complete (Table II).

Role of the late components of complement in the serumdependent killing of E. coli by rabbit PMN. Because the antibacterial properties of nonimmune serum toward $E$. coli are mainly attributable to the cytotoxic C5-9 complex (17), we examined the effect of interference with its formation by depleting NHS of C7. Fig. 6 (solid lines) shows that the enhancing effect of serum on PMN-mediated killing of $E$. coli $\mathrm{J} 5$ was almost completely eliminated by the removal of $\mathrm{C} 7$ from the serum (compare solid squares with solid triangles). Repletion of $\mathrm{C} 7$ to the C7-D serum fully restored the enhancing activity. 


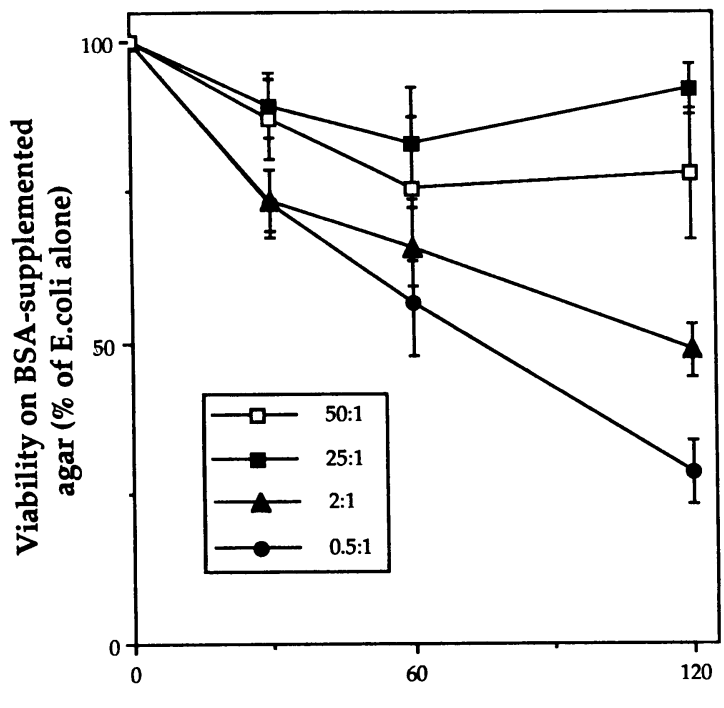

Time (min)

Figure 3. Effect of $E$. coli/PMN ratio on rescue by BSA of $E$. coli ingested by rabbit PMN. E. coli $\mathrm{J} 5$ at a concentration of $1,4,50$, or $100 \times 10^{7}$ bacteria/ml were incubated at $37^{\circ} \mathrm{C}$ with rabbit PMN $(2$ $\times 10^{7} / \mathrm{ml}$ ) in the standard incubation mixture. At the indicated time points after adding PMN, samples were placed on ice and bacterial viability with or without BSA $(1 \mathrm{mg} / \mathrm{ml})$ in the growth medium was measured as described in Methods. Data shown represent the mean \pm SEM of bacterial viability on BSA-supplemented agar determined in at least four experiments. In all cases, bacterial viability was $<1 \%$ in the absence of BSA and $>90 \%$ in the absence of PMN. The differences in viability after incubation for $120 \mathrm{~min}$ at $E$. coli/ PMN ratios of 25:1 and 50:1 were not statistically significant compared with the results obtained at a ratio of 10:1 (see Fig. 1), but were significant at ratios of 2:1 and 0.5:1 $(P<0.001)$.

In all circumstances, the impairment of protein synthesis by the ingested bacteria closely paralleled the diminishing bacterial colony formation in BSA-supplemented nutrient agar (Fig. 6 , dotted lines). A small reduction in colony formation in BSA-supplemented nutrient agar was observed after ingestion in the presence of C7-D serum (compare Figs. 1 and 6), suggesting that other serum factors may play a minor role in enhancing killing by the PMN.

Depletion of $\mathrm{C} 7$ also resulted in prolonged intracellular survival of smooth $E$. coli. Ingestion of $E$. coli ML-35 after opsonization with C7-D serum promptly triggered loss of colony formation in nutrient agar but not in BSA-supplemented growth medium (Fig. 7, left). Even more striking, ingested $E$. coli O1 11:B4 remained fully capable of growth in nutrient agar both in the presence and absence of BSA (Fig. 7, right) despite efficient uptake (Fig. 7, right, dotted line). Under these conditions, $E$. coli $\mathrm{O} 11$ :B4, unlike ingested rough $E$. coli (4-6), also retain their outer membrane permeability barrier to actinomycin $\mathrm{D}$ and do not undergo appreciable phospholipid degradation (data not shown), suggesting that $E$. coli $\mathrm{O} 111$ :B4 also escape all detectable envelope alterations.

Role of late components of complement in killing of E. coli by human PMN. Similar experiments were carried out with human PMN to determine whether these phagocytes also re- quire late components of complement for killing of ingested $E$. coli. As shown for rabbit PMN, after ingestion in the presence of nonlethal concentrations of NHS, the smooth $E$. coli strain O111:B4 promptly stopped forming colonies in nutrient agar either without or with BSA (Fig. 8, right, circles), but these bacteria ingested after opsonization with C7-D serum retained colony-forming ability in both growth media (Fig. 8, right, squares). Rough $E$. coli $\mathrm{J} 5$, opsonized with nonlethal doses of NHS, were also rapidly killed after phagocytosis (Fig. 8, left, circles). After opsonization with C7-D serum, however, a substantial fraction of these bacteria ingested by human PMN, although not growing in normal nutrient agar, remained viable in BSA-supplemented nutrient agar (Fig. 8, left, squares). As opposed to rabbit PMN (either from peritoneal exudates or peripheral blood), human PMN do not ingest rough $E$. coli in the absence of serum opsonins $(9,18)$. Thus, the fate of rough $E$. coli ingested by human PMN in the absence of serum could not be determined.

Killing of $S$. epidermidis by rabbit PMN. In contrast to the gram-negative bacteria tested, the gram-positive $S$. epidermidis, ingested after opsonization with either NHS or C7-D serum, rapidly lose their ability to form colonies (in both normal and BSA-supplemented nutrient agar) and, in parallel, cease protein synthesis (Fig. 9). Therefore, PMN effectively kill these gram-positive bacteria without a need for the late complement components.

Relation of intracellular bacterial killing to the respiratory burst of the PMN. Phagocytosis of rough E. coli by rabbit PMN in the absence of serum triggered a 10-fold increase in glucose oxidation via the hexose monophosphate shunt (Table III), reflecting activation of the respiratory burst, within the range reported in the literature (20-23). Addition of nonlethal amounts of serum to promote killing of $E$. coli did not increase the magnitude of this response, nor did ingestion and rapid killing of $S$. epidermidis. Hence, differences in bacterial killing by PMN do not reflect differences in oxidative response.

Effect of serum on killing of E. coli by purified BPI. BPI is a major component of the PMN's arsenal against $E$. coli, and the early effects of BPI and intact PMN on $E$. coli are closely similar $(1,2,6,9,19,24)$. We therefore examined the effect of NHS on colony formation by BPI-treated $E$. coli J5 or O111:B4. Colony formation was almost immediately arrested when $E$. coli $\mathrm{J} 5$ were plated in nutrient agar (not shown; reference 7$)$, but only slowly $\left(t_{1 / 2}>2 \mathrm{~h}\right)$ when plated in nutrient agar plus BSA (Fig. 10, left, open circles). Pretreatment of $E$. coli $\mathrm{J} 5$ with nonlethal concentrations of NHS before adding BPI accelerated loss of colony formation in BSA-supplemented nutrient agar ( $\left.t_{1 / 2} 30-40 \mathrm{~min}\right)$ (Fig. 10, left, solid circles). This effect of serum on killing by BPI, as shown above for intact PMN, is abolished after removal of C7 (Fig. 10, left, solid squares) and is restored when the C7-D serum is repleted with purified $\mathrm{C} 7$ (Fig. 10, left, triangles). In contrast, pretreatment of $E$. coli O111:B4 with either C7-D or normal serum has no effect on the rate of killing by BPI (Fig. 10, right).

\section{Discussion}

The PMN is equipped with many $\mathrm{O}_{2}$-dependent as well as $\mathrm{O}_{2}$-independent antimicrobial agents, acting on a wide range of pathogens $(6,25)$. Despite this broad spectrum and seem- 

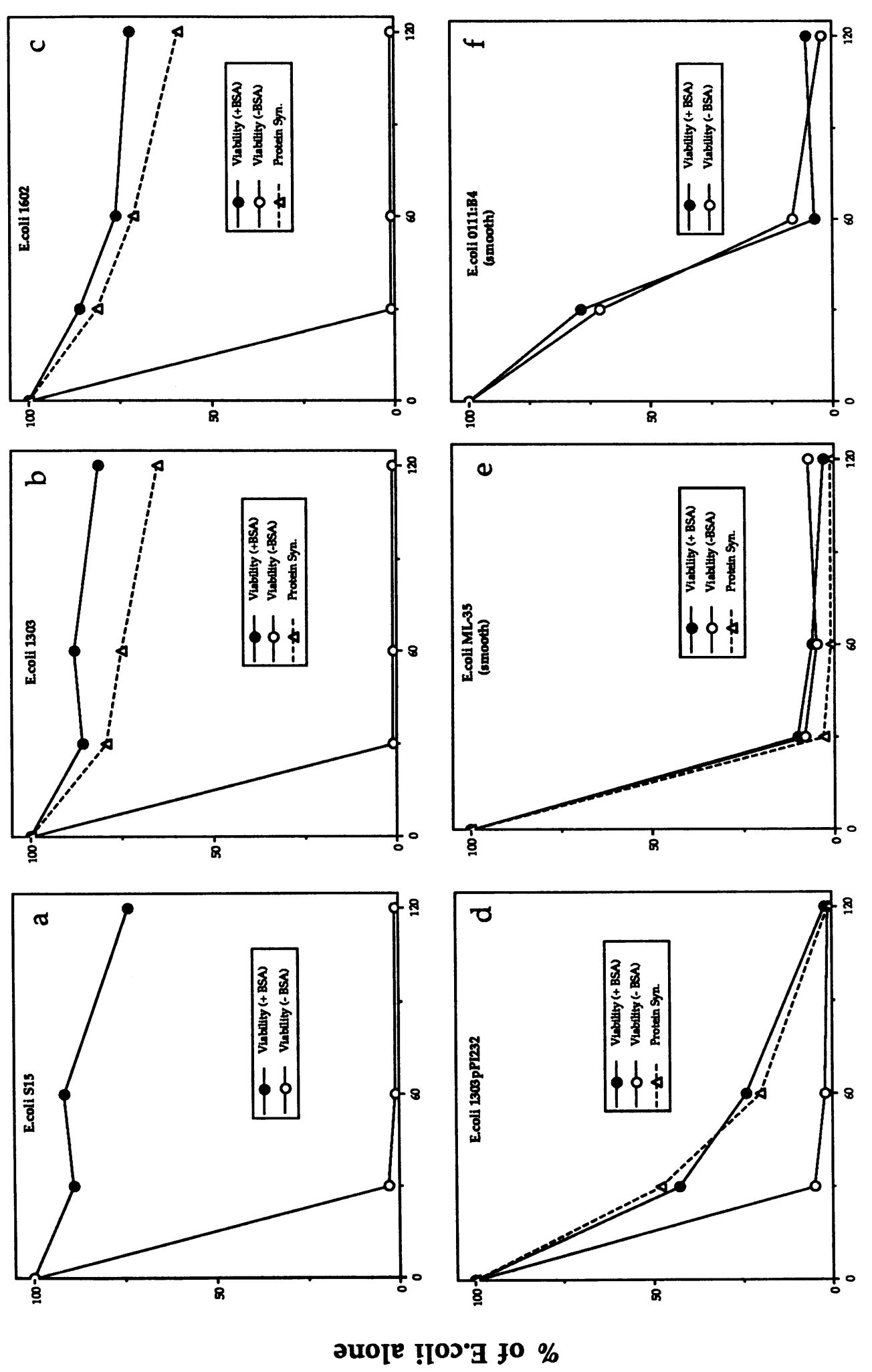

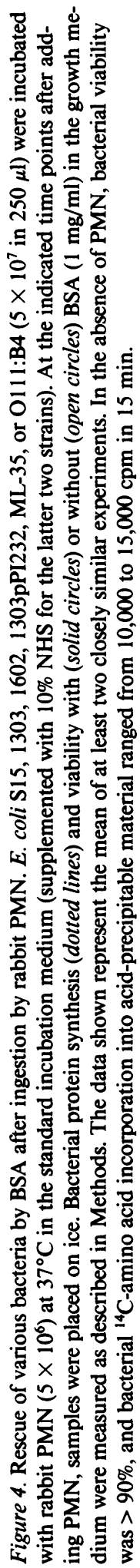




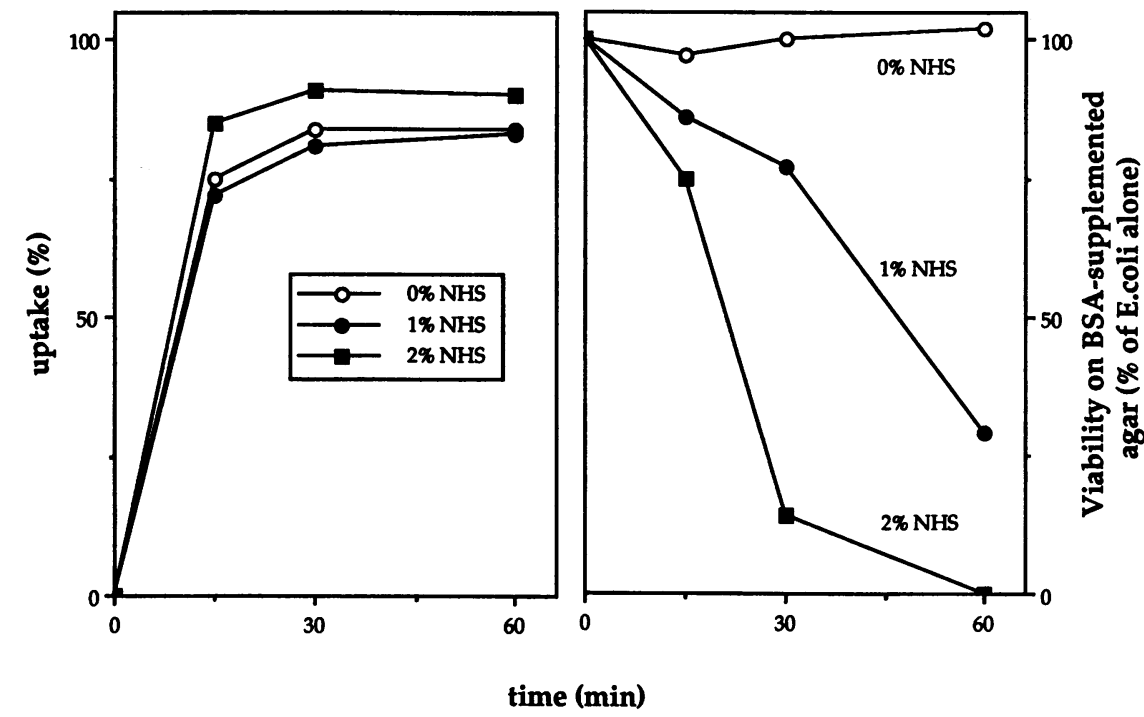

Figure 5. Effect of nonlethal concentrations of NHS on uptake and killing of $E$. coli 1303 by rabbit PMN. $\left[{ }^{14} \mathrm{C}\right] \mathrm{Oleate}-\mathrm{labeled}$ E. coli 1303 $\left(5 \times 10^{7}\right.$ in $\left.250 \mu \mathrm{l}\right)$ were preincubated for 10 min at $37^{\circ} \mathrm{C}$ in the presence of the indicated concentration of NHS, at which time rabbit $\operatorname{PMN}\left(5 \times 10^{6}\right)$ were added $(t=0 \mathrm{~min})$ and the incubation was continued at $37^{\circ} \mathrm{C}$. At the indicated time points after adding PMN, bacterial uptake (left) and viability with or without BSA $(1 \mathrm{mg} / \mathrm{ml})$ in the growth medium (right) were measured as described in Methods. In all cases, bacterial viability was $<1 \%$ in the absence of BSA in the growth medium, and bacterial viability in the absence of PMN was $>90 \%$. The data shown represent the results of one of three closely similar experiments. ingly redundant antimicrobial arsenal, $E$. coli that have been ingested by PMN, although unable to form colonies on nutrient agar, continue to incorporate radiolabeled precursors into macromolecules and respond appropriately to environmental changes with adjustments in biochemical activity (4-6). Because we have found that loss of colony formation, but continued biosynthesis, by $E$. coli after treatment with an antibacterial protein (BPI) of the PMN reflects bacteriostasis and not bacterial death (7), we have reexamined in this study the fate of $E$. coli during phagocytosis. We show that of the ingested $E$. coli that do not grow on nutrient agar, large portions $(>75 \%)$ are, in fact, not dead but can resume growth when the culture medium is supplemented with $0.1 \%$ BSA. Rescue is possible for several hours after ingestion is complete

Table I. Sensitivity of E. coli J5 to Serum Preparations

\begin{tabular}{rccc}
\hline & \multicolumn{3}{c}{ Bacterial CFU } \\
\cline { 2 - 4 } & NHS & C7-D serum & $\begin{array}{c}\text { C7-reconstituted } \\
\text { serum }\end{array}$ \\
\hline & & $\%$ & \\
$1 \%$ & $98.9 \pm 0.6$ & $99.2 \pm 0.3$ & $101 \pm 1.4$ \\
$2 \%$ & $96 \pm 1.6$ & - & - \\
$3 \%$ & $87 \pm 4.4$ & - & $96.6 \pm 2.0$ \\
$4 \%$ & $54.5 \pm 2.5$ & - & - \\
$5 \%$ & $26.6 \pm 4.3$ & $98.0 \pm 0.5$ & $81.0 \pm 3.8$ \\
$8 \%$ & 0 & - & $41.0 \pm 4.1$ \\
$10 \%$ & - & $97.7 \pm 1.1$ & $0.8 \pm 0.2$ \\
$15 \%$ & - & - & 0 \\
$20 \%$ & - & $91.3 \pm 3$ & - \\
& & & \\
\hline
\end{tabular}

E. coli $\mathrm{J} 5\left(2 \times 10^{8} / \mathrm{ml}\right)$ were incubated at $37^{\circ} \mathrm{C}$ for $30 \mathrm{~min}$ in the presence of increasing amounts of NHS, C7-D serum, or C7-D serum to which had been added purified $\mathrm{C} 7$ to a final concentration of $50 \mu \mathrm{g} / \mathrm{ml}$ (C7-reconstituted serum). Bacterial viability was then determined as described in Methods. Data represent the mean \pm SEM of four experiments. and parallels the extent of preservation of metabolic activity (Figs. 1 and 3).

The surprising finding that most of the apparently nonviable $E$. coli can be rescued several hours after their sequestration by PMN must raise questions about the adequacy of the performance of the PMN in vitro. However, we have found no evidence in these experiments that the PMN failed in any of its characteristic responses to added bacteria: ( $a$ ) Ingestion: ingestion was prompt and essentially complete over a wide range of bacteria/PMN ratios. That the $E$. coli were truly intracellular was verified by electron microscopy (Fig. 2). Moreover, demonstration of rescue required lysis of the PMN by sonication. Further, the serum-mediated acceleration of irreversible growth inhibition (see also below) was only produced when the

Table II. Effect of NHS and/or PMN on Viability of E. coli J5

\begin{tabular}{lrrr}
\hline & \multicolumn{2}{c}{$\begin{array}{c}\text { Bacterial CFU after } \\
\text { E0-min incubation }\end{array}$} \\
\cline { 2 - 4 } \multicolumn{1}{c}{ E. coli J5 plus: } & \multicolumn{1}{c}{-BSA } & +BSA \\
\hline & 100 & 104 \\
PMN & 2 & 79 \\
NHS & 94 & 93 \\
PMN + NHS & 3 & 6 \\
NHS pretreatment + PMN & 1 & 11 \\
NHS-pretreated PMN & 4 & 86 \\
PMN, followed by NHS after 30 min & 1 & 80 \\
& & & \\
\hline
\end{tabular}

E. coli $\mathrm{J} 5\left(2 \times 10^{8} / \mathrm{ml}\right.$ final concentration $)$ were included in the standard incubation mixture with PMN $\left(2 \times 10^{7} / \mathrm{ml}\right.$ final concentration) and/or 2\% NHS. Where indicated, either the bacteria or the PMN were first treated with $2 \% \mathrm{NHS}$ for $30 \mathrm{~min}$ at $37^{\circ} \mathrm{C}$, followed by removal of the serum by centrifugation before beginning the $E$. coliPMN incubation. Bacterial viability was determined after $60 \mathrm{~min}$ as described in Methods. Data represent the mean of at least two closely similar experiments. 


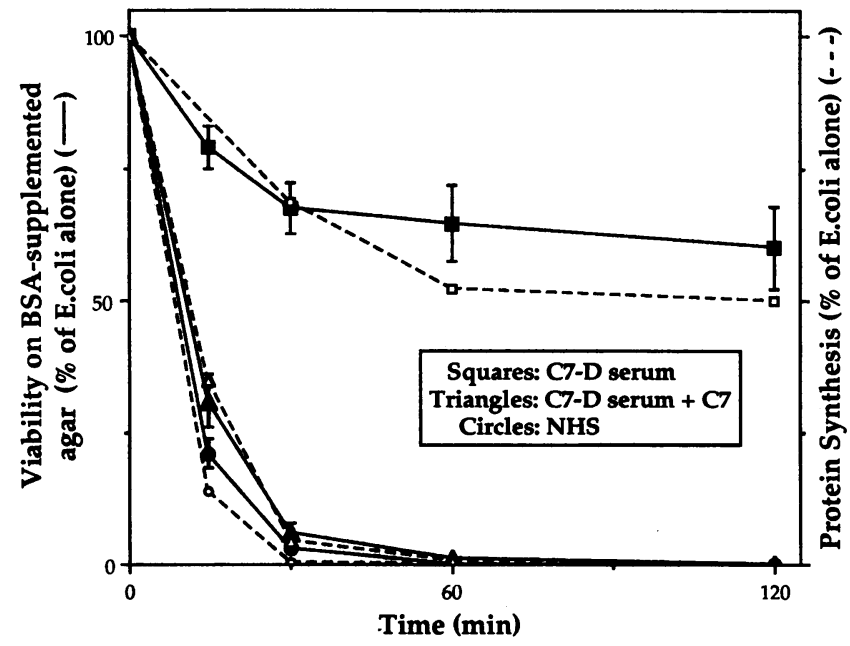

Figure 6. Fate of $E$. coli $\mathrm{J} 5$ incubated with rabbit PMN in the presence of normal, C7-D, and C7-reconstituted human serum. E. coli $\mathrm{J} 5\left(5 \times 10^{7}\right.$ in $\left.250 \mu \mathrm{l}\right)$ were incubated with rabbit PMN $\left(5 \times 10^{6}\right)$ at $37^{\circ} \mathrm{C}$ in the standard incubation medium with $2 \%$ NHS (circles), $4 \%$ C7-D serum (squares), or 4\% C7-D serum to which purified C7 was added (final concentration $=50 \mu \mathrm{g} / \mathrm{ml}$; triangles). At the indicated time points after adding PMN, bacterial viability with BSA (1 $\mathrm{mg} / \mathrm{ml}$ ) in the growth medium (solid lines) and protein synthesis (dotted lines) were measured as described in Methods. The data shown represent the mean \pm SEM of at least four experiments in the case of bacterial viability and the mean of two closely similar experiments in the case of protein synthesis. In all cases, bacterial viability was $<1 \%$ in normal nutrient agar and $>90 \%$ in the absence of $\mathrm{PMN}$, and ${ }^{14} \mathrm{C}$-amino acid incorporation into acid-precipitable material in the absence of PMN was $\sim 12,000 \mathrm{cpm}$ in $15 \mathrm{~min}$.

serum was added to the incubation mixture before, not after, ingestion had taken place (Table II). (b) Respiratory burst: the stimulation of ${ }^{14} \mathrm{CO}_{2}$ production from $\left[1-{ }^{14} \mathrm{C}\right]$ glucose is $\sim 10$ - fold over resting values (i.e., within the range found by other investigators studying antimicrobial activity of PMN in vitro [20-23]), and the same upon addition of $E$. coli with or without NHS, or of S. epidermidis (Table III). (c) Bactericidal activity: in contrast to the intracellular survival of both rough and smooth $E$. coli, $S$. epidermidis promptly lost viability (both in nutrient agar and in nutrient agar supplemented with BSA) and protein-biosynthetic activity (Fig. 9). We cannot attribute the prolonged intracellular survival of $E$. coli merely to limiting amounts of antimicrobial factors under our experimental conditions of relatively high bacteria/PMN ratios, because even at $0.5: 1$, half of the ingested $E$. coli can be rescued after $1 \mathrm{~h}$ (Fig. 3). Thus, the conclusion seems justified that the PMN, while effective at bacteriostasis of $E$. coli, is unexpectedly inefficient at killing these bacteria, raising new questions about host-defense against gram-negative bacterial infection.

Others have shown before that the fate of intracellular bacteria can be affected by serum $(26,27)$. This study confirms and extends these earlier observations showing that pretreatment of a wide range of $E$. coli strains with nonlethal concentrations of NHS contribute to the subsequent killing by rabbit and human PMN. This effect of serum is also apparent at low bacteria/PMN ratios (not shown), indicating that killing of the relatively small numbers of bacteria ingested under the usual clinical conditions is also rendered more efficient by serum. The close temporal association between loss of bacterial metabolic activity and the progressive loss of viability in albuminsupplemented nutrient agar lends credence to our contention that colony formation in this growth medium is a valid measure of bacterial death (7; Figs. 4, 6, and 9).

Tedesco et al. have implicated the late components of complement in the killing of E. coli $(\mathrm{O} 111$ :B4 by human PMN (27). The ineffectiveness of C7-D serum in enhancing the bactericidal activity of rabbit PMN towards several rough and smooth $E$. coli strains coupled with its restoration when $\mathrm{C} 7$ is re-added (Figs. 6 and 7) also points to the importance of the

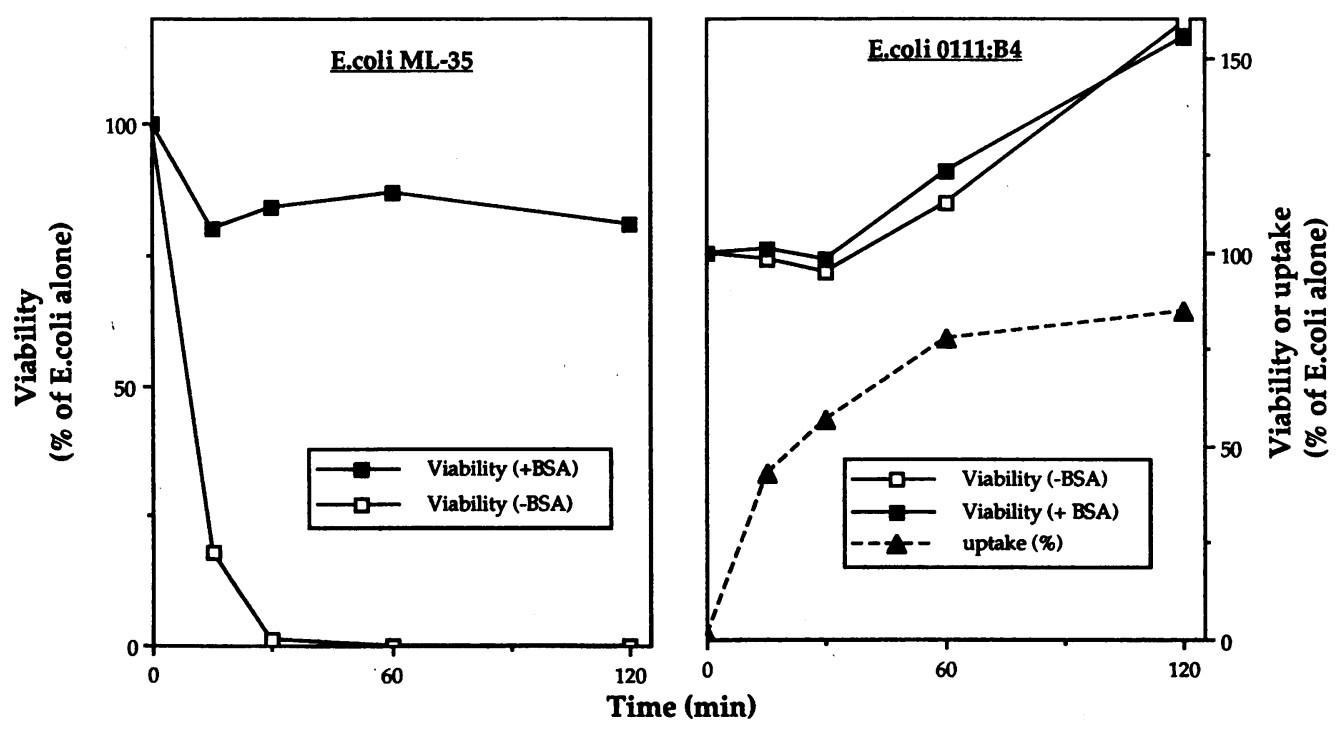

Figure 7. Fate of $E$. coli $\mathrm{ML}$ 35 and $0111: B 4$ incubated with rabbit PMN in the presence of C7-D serum. $E$. coli ML-35 (left) or E. coli O111:B4 prelabeled with $\left[{ }^{14} \mathrm{C}\right]-$ oleic acid, $5 \times 10^{7}$ in $250 \mu l$ (right) were incubated with rabbit PMN $\left(5 \times 10^{6}\right)$ at $37^{\circ} \mathrm{C}$ in the standard incubation medium in the presence of C7-D serum (10\% for $E$. coli $\mathrm{ML}-35$ and $20 \%$ for $E$. coli O111:B4). At the indicated time points after adding PMN, bacterial uptake (dotted lines) and viability with (solid squares) or without (open squares) BSA (1 $\mathrm{mg} / \mathrm{ml}$ ) in the growth medium were measured as described in Methods. The data shown represent the mean of at least two closely similar experiments. Bacterial viability in the absence of PMN was $>90 \%$. 


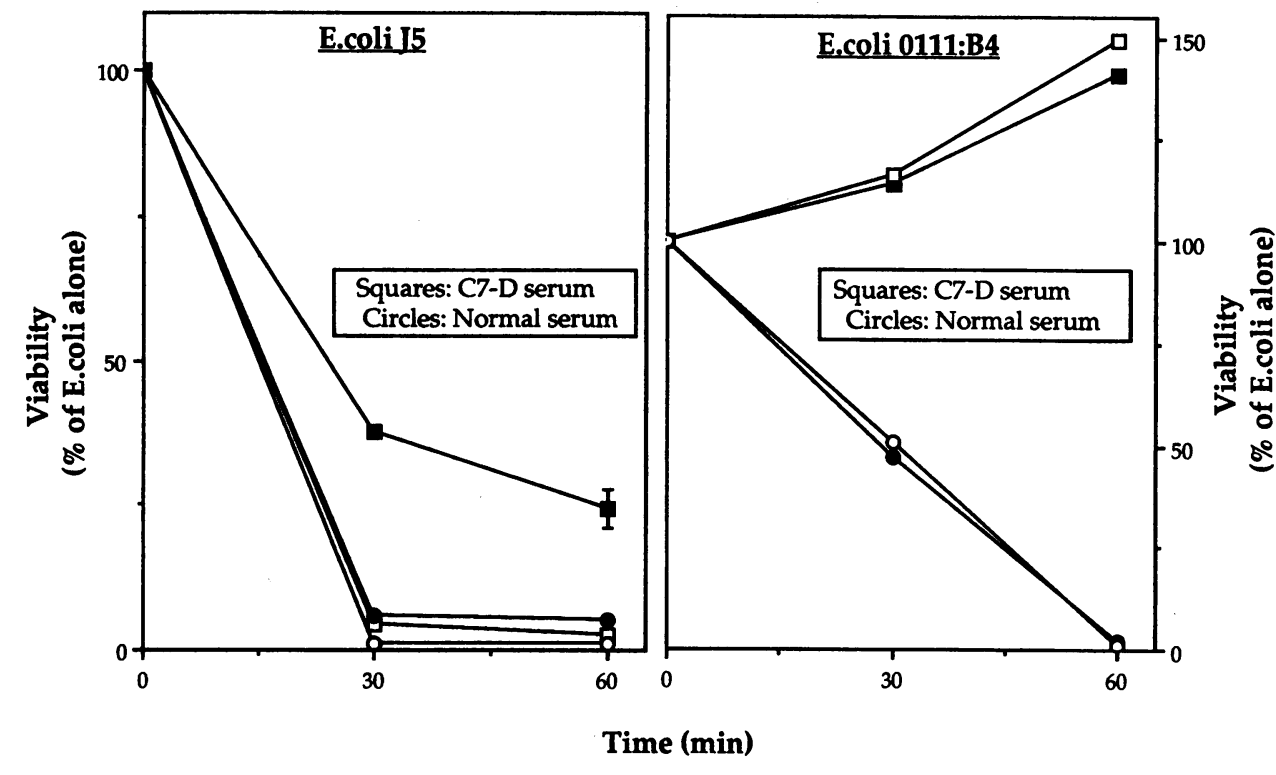

Figure 8. Fate of $E$. coli $\mathrm{J} 5$ and O111:B4 incubated with human $P M N$ in the presence of normal and C7-D human serum. E. coli J5 (left) or O111:B4 (right) $\left(5 \times 10^{7}\right.$ in 250 $\mu$ l) were incubated with human $\operatorname{PMN}\left(5 \times 10^{6}\right)$ at $37^{\circ} \mathrm{C}$ in the standard incubation medium with NHS (circles) (2\% for $\mathrm{J} 5$ and $12.5 \%$ for O111:B4) or C7-D serum (squares) (4\% for J5 and $20 \%$ for O111:B4). At the indicated time points after adding PMN, bacterial viability with (solid symbols) or without (open symbols) BSA $(1 \mathrm{mg} / \mathrm{ml})$ in the growth medium was measured as described in Methods. The data shown represent the mean of three separate determinations. Bacterial viability in the absence of PMN was $>90 \%$. formation of a cytotoxic complement complex in the extracellular environment to the intracellular fate of ingested $E$. coli. This effect of the late components of complement must precede ingestion; addition of NHS after phagocytosis is complete does not result in more rapid killing (Fig. 5). These findings differ from observations on the enhancement of intracellular killing by human monocytes of Staphylococcus aureus (26), which has been attributed to the interaction of complement components with receptors on the phagocyte surface. However, in our experiments with PMN the serum effect need not depend solely on interaction with the bacteria (Table II), but may also include subsequent effects of serum components fixed to the bacteria on the PMN.

How nonlethal concentrations of NHS prepare the bacteria for more rapid intracellular destruction has not been determined. It appears likely that the cytotoxic complement complex can produce some outer membrane alterations that, while insufficient to interfere with bacterial viability, render the $E$. coli more vulnerable to the PMN's antimicrobial agents (28, 29). Other envelope-damaging factors may influence the rate of intracellular destruction of gram-negative bacteria. An $E$. coli strain (1303pPI232), enriched in an outer membrane-associated phospholipase $A(12)$ that hydrolyzes large portions of the bacterial phospholipids when activated during phagocytosis, also undergoes accelerated killing (Fig. $4 d$; reference 13).

The remarkably similar separation of sublethal and lethal effects (and their reduction by added nonlethal amounts of NHS) when rough $E$. coli strains are exposed to intact PMN

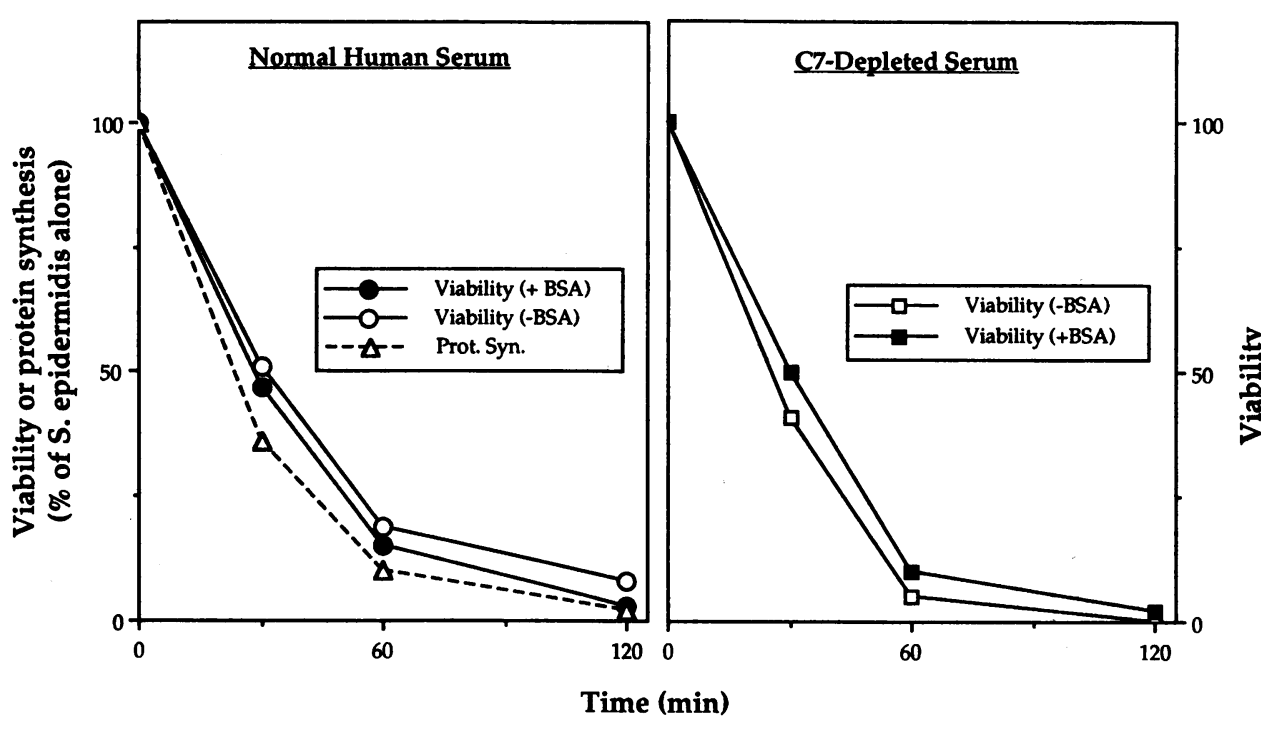

Figure 9. Fate of $S$. epidermis incubated with rabbit PMN in the presence of normal and C7-D human serum. $S$. epidermis $\left(5 \times 10^{7}\right.$ in $\left.250 \mu l\right)$ were incubated with rabbit PMN $(5 \times$ $10^{6}$ ) at $37^{\circ} \mathrm{C}$ in the standard incubation medium with $10 \%$ NHS (left) or $20 \%$ C7-D serum $(r i g h t)$. At the indicated times, bacterial protein synthesis (dotted lines) and viability (solid lines) were measured, the latter with (solid symbols) or without (open symbols) BSA $(1 \mathrm{mg} / \mathrm{ml})$ in the growth medium as described in Methods. The data shown represent the mean of three separate determinations. In the absence of PMN, bacterial viability was $>90 \%$, and ${ }^{14} \mathrm{C}$-amino acid incorporation into acid-precipitable material was $\sim 12,000 \mathrm{cpm}$ in $15 \mathrm{~min}$. 
Table III. Stimulation of Hexose Monophosphate Shunt Activity of PMN during Phagocytosis

\begin{tabular}{|c|c|c|c|c|}
\hline & \multicolumn{4}{|c|}{${ }^{14} \mathrm{CO}_{2}$ produced } \\
\hline & \multicolumn{2}{|c|}{-NHS } & \multicolumn{2}{|c|}{+ NHS } \\
\hline & $15 \mathrm{~min}$ & $30 \mathrm{~min}$ & $15 \min$ & $30 \mathrm{~min}$ \\
\hline & \multicolumn{4}{|c|}{ nmol } \\
\hline PMN alone & 2.7 & 4.9 & 2.7 & 5.2 \\
\hline $\mathrm{PMN}+$ E. coli $\mathrm{J} 5$ & 20.9 & 50.0 & 21.6 & 50.2 \\
\hline $\mathrm{PMN}+S$. epidermidis & - & - & 20.6 & 49.4 \\
\hline
\end{tabular}

$E$. coli $\mathrm{J} 5$ or $S$. epidermidis $\left(1 \times 10^{8}\right)$ were incubated in $0.5 \mathrm{ml}$ of the standard incubation medium with or without rabbit PMN $\left(1 \times 10^{7}\right)$ in the presence or absence of $2 \%$ NHS with added $\left[1-{ }^{14} \mathrm{C}\right] \mathrm{D}$-glucose (final glucose concentration $=30 \mathrm{mg} / \mathrm{ml}$ ). At the indicated time points, production of ${ }^{14} \mathrm{CO}_{2}$ was measured as described in Methods. The data represent the mean of two closely similar experiments.

and purified BPI (Fig. 10, left) is consistent with a major role for BPI in the action of PMN on these BPI-sensitive bacteria. A primary role of BPI is further supported by our recent observations showing the preferential binding to $E$. coli of BPI in crude PMN extracts that contain a multitude of antibacterial proteins and peptides (30), and by the finding that the separation of sublethal and lethal effects is not evident when BPI-insensitive $S$. epidermidis are ingested by PMN (Fig. 9). It is still unclear, however, why in the absence of serum (or late complement components) the lethal action of intact PMN on ingested $E$. coli, in particular smooth $E$. coli $\mathrm{O} 111: \mathrm{B} 4$, is more limited than that of purified BPI (Figs. $4 f$ and 10, right) and why the late complement components dramatically enhance killing of these smooth bacteria by PMN, but not by isolated BPI.
Although the addition of serum albumin to the growth medium (nutrient agar) permits the resumption of growth by many ingested $E$. coli after their release from the PMN, the presence of albumin in the extracellular medium of the incubation mixture has no effect on the fate of the ingested bacteria. Thus, the length of intracellular survival of rough $E$. coli ingested by rabbit PMN in the absence of serum was the same whether or not albumin was added. Further, NHS accelerates the killing of $E$. coli by rabbit PMN despite the high albumin content of serum. Perhaps not enough albumin, in contrast to certain other serum constituents, can reach the phagolysosome. In addition, the effect of albumin may be overcome by other, more potent serum constituents.

In conclusion, these studies demonstrate that the traditional assay for bacterial viability in nutrient agar may fail to measure adequately the bactericidal activity of host-defense systems. We have shown that a simple modification of the growth medium can restore growth by phagocytosed bacteria unable to grow on nutrient agar. Therefore, PMN can promptly inhibit multiplication of ingested $E$. coli without actually causing death. The continued metabolic activity of ingested $E$. coli, and its termination when the bacteria are pretreated with nonlethal NHS, shows that loss of metabolic activity, which coincides with apparently irreversible growth inhibition, provides a valid measure of bacterial killing. The results also show that factors (late components of complement) in serum are needed to improve the relatively inefficient bactericidal activity of the PMN against gram-negative bacteria. Preliminary observations show the same enhancement by inflammatory exudate fluid, further demonstrating the integration of extracellular factors in intracellular microbicidal events. Thus, the importance of the complement system, in addition to its established role in mobilizing the cellular elements and promoting phagocytosis, includes the amplification of the destructive capabilities of the phagocyte toward ingested microorganisms. These studies set the stage for a further exam-

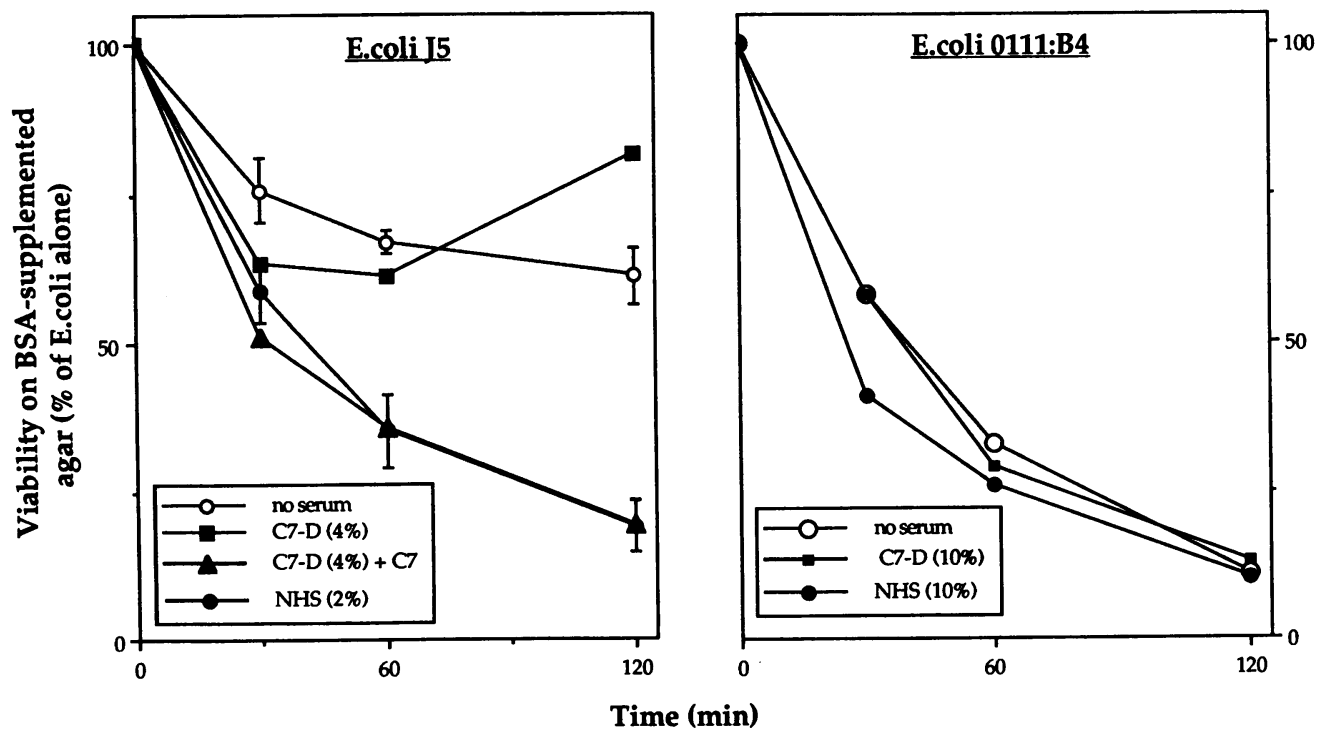

Figure 10. Effect of pretreatment of $E$. coli $\mathrm{J} 5$ or $E$. coli O111:B4 with normal, C7-D, and C7-repleted human serum on bacterial killing during incubation with BPI. E. coli J5 (left) or E. coli O111:B4 (right) $\left(2 \times 10^{8} / \mathrm{ml}\right)$ were incubated for $30 \mathrm{~min}$ at $37^{\circ} \mathrm{C}$ in the standard incubation medium without serum (open circles), or with NHS (solid circles), C7-D serum (squares), or C7-D serum to which had been added purified $\mathrm{C} 7$ to a final concentration of $50 \mu \mathrm{g} / \mathrm{ml}$ (triangles). After removal of the unbound serum by centrifugation, the bacteria were resuspended in an equal volume of the standard incubation

medium. Purified rabbit BPI was then added $\left(4 \mu \mathrm{g} / 10^{7}\right.$ E. coli $\mathrm{J} 5$ and $15 \mu \mathrm{g} / 10^{7}$ E. coli O111:B4), and incubation was continued at $37^{\circ} \mathrm{C}$. At the indicated time points after BPI addition, viability in BSA-supplemented nutrient agar was measured as described in Methods. Bacterial viability was $<1 \%$ in the absence of BSA in the growth medium and $>90 \%$ in the absence of BPI. 
ination of the coordination of cellular and extracellular elements in antibacterial host defense, not only in the killing, but also in the ultimate digestion and disassembly of microbial invaders.

\section{Acknowledgments}

We are grateful for the electron microscopy carried out by Dr. KwangShin Kim, Department of Microbiology, New York University School of Medicine, and for the technical help of Johnny Tang.

This work was supported by the United States Public Health Service grant R37DK 05472, and the American Cancer Society grant MV-321. B. A. Mannion was supported by National Institutes of Health training grant 5T32 GM-07308 from the National Institute of General Medical Sciences.

\section{References}

1. Weiss, J., P. Elsbach, I. Olsson, and H. Odeberg. 1978. Purification and characterization of a potent bactericidal and membrane active protein from the granules of human polymorphonuclear leukocytes. $J$. Biol. Chem. 253:2664-2672.

2. Elsbach, P., J. Weiss, R. C. Franson, S. Beckerdite-Quagliata, A. Schneider, and L. Harris. 1979. Separation and purification of a potent bactericidal/permeability increasing protein and a closely related phospholipase A2 from rabbit polymorphonuclear leukocytes: observations on their relationship. J. Biol. Chem. 254:11000-11009.

3. Weiss, J., and I. Olsson. 1987. Cellular and subcellular localization of the bactericidal/permeability increasing protein of neutrophils. Blood. 69:652-659.

4. Elsbach, P., P. Pettis, S. Beckerdite, and R. C. Franson. 1973. The effect of phagocytosis by rabbit granulocytes on macromolecular synthesis and degradation in different species of bacteria. J. Bacteriol. 115:490-497.

5. Beckerdite, S., C. Mooney, J. Weiss, R. C. Franson, and P. Elsbach. 1974. Early and discrete changes in permeability of $E$. coli and certain other gram negative bacteria during killing by granulocytes. J. Exp. Med. 140:396-409.

6. Elsbach, P., and J. Weiss. 1988. Phagocytic cells: $\mathrm{O}_{2}$-independent antimicrobial systems. In Inflammation: Basic Principles and Clinical Correlates. J. I. Gallin, I. M. Goldstein, and R. Snyderman, editors. Raven Press, New York, 445-470.

7. Mannion, B. A., J. Weiss, and P. Elsbach. 1990. Separation of sublethal and lethal effects of the bactericidal/permeability increasing protein on Escherichia coli. J. Clin. Invest. 85:853-860.

8. Elsbach, P., and I. L. Schwartz. 1959. Studies on the sodium and potassium transport in rabbit polymorphonuclear leukocytes. J. Gen. Physiol. 42:883-898.

9. Weiss, J., L. Kao, M. Victor, and P. Elsbach. 1985. Oxygen-independent intracellular and oxygen dependent extracellular killing of Escherichia coli $\mathrm{S} 15$ by human polymorphonuclear leukocytes. $J$. Clin. Invest. 76:206-212.

10. Fraker, P. J., and J. C. Speck. 1978. Protein and cell membrane iodinations with a sparingly soluble chloramide, 1,3,4,6 tetrachloro3a,6a-diphenylglycoluril. Biochem. Biophys. Res. Commun. 80:849857.

11. Simon, E. J., and D. van Praag. 1964. Inhibition of RNA synthesis in Escherichia coli by levorphanol. Proc. Natl. Acad. Sci. USA. 51:877-883.

12. DeGeus, P., I. vanDie, H. Bergmans, J. Tommasson, and G. deHaas. 1983. Molecular cloning of pldA, the structural gene for outer membrane phospholipase of E. coli K12. Mol. \& Gen. Genet. 190:150-155.

13. Wright, G. C., J. Weiss, K. S. Kim, V. H. Verheij, and P.
Elsbach. 1990. Bacterial phospholipid hydrolysis enhances the destruction of Escherichia coli ingested by rabbit neutrophils. Role of cellular and extracellular phospholipases. J. Clin. Invest. 85:1925-1935.

14. Wurster, N., P. Elsbach, E. J. Simon, P. Pettis, and S. Lebow. 1971. The effects of the morphine analogue levorphanol on leukocytes. Metabolic effects at rest and during phagocytosis. J. Clin. Invest. 50:1091-1099.

15. Kellenberger, E., A. Ryter, and J. Sechaud. 1958. Electron microscopic study of DNA-containing plasms. II. Vegetative and mature phage DNA as compared with normal bacterial nucleoids in different physiological states. J. Biophys. Biochem. Cytol. 4:671-678.

16. Frasca, J. M., and V. R. Parks. 1965. A routine technique for double-staining ultrathin sections using uranyl and lead salts. J. Cell Biol. 25:157-161.

17. Joiner, K. A., E. J. Brown, and M. M. Frank. 1984. Complement and bacteria: chemistry and biology in host defense. Annu. Rev. Immunol. 2:461-491.

18. Stendahl, O., and L. Edebo. 1972. Phagocytosis of mutants of Salmonella typhimurium by rabbit polymorphonuclear cells. Acta Pathol. Microbiol. Scand. Sect. B. 80:481-488.

19. Weiss, J., M. Victor, O. Stendahl, and P. Elsbach. 1982. Killing of Gram-negative bacteria by polymorphonuclear leukocytes. Role of an $\mathrm{O}_{2}$-independent bactericidal system. J. Clin. Invest. 69:959-970.

20. Stahelin, H., M. L. Karnovsky, A. E. Farnham, and E. Suter. 1957. Studies on the interaction between phagocytes and tubercle bacilli III. Some metabolic effects in guinea pigs associated with infection with tubercle bacilli. J. Exp. Med. 105:265-277.

21. Sbarra, A. J., and M. L. Karnovsky. 1959. The biochemical basis of phagocytosis. I. Metabolic changes during the ingestion of particles by polymorphonuclear leukocytes. J. Biol. Chem. 234:13551362.

22. Elsbach, P. 1965. Uptake of fat by phagocytic cells: an examination of the role of phagocytosis. I. Rabbit polymorphonuclear leukocytes. Biochim. Biophys. Acta. 98:402-419.

23. Simberkoff, M. S., and P. Elsbach. 1971. The interaction between polymorphonuclear leukocytes and mycoplasma. J. Exp. Med. 134:1417-1430.

24. Gabay, J. E., R. W. Scott, D. Campanelli, J. Griffith, C. Wilde, M. N. Marra, M. Seeger, and C. Nathan. 1989. Antibiotic proteins of polymorphonuclear leukocytes. Proc. Natl. Acad. Sci. USA. 86:56105614.

25. Klebanoff, S. J. 1988. Phagocytic cells: products of $\mathrm{O}_{2}$ metabolism. In Inflammation: Basic Principles and Clinical Correlates. J. I. Gallin, I. M. Goldstein, and R. Snyderman, editors. Raven Press, New York. 391-444.

26. Leijh, P. C., M. van den Barselaar, T. van Zwet, M. R. Daha and R. van Furth. 1979. Requirement of extracellular complement and immunoglobulin for intracellular killing of microorganisms by human monocytes. J. Clin. Invest. 63:772-784.

27. Tedesco, F., G. Rottini, and P. Patriarca. 1981. Modulating effect of the late-acting components of the complement system on the bactericidal activity of human polymorphonuclear leukocytes on $E$. coli O111:B4. J. Immunol. 127:1910-1915.

28. Vernon, L. T., R. L. Duncan, Jr., and D. C. Morrison. 1986. The interaction of Escherichia coli with normal human serum: the kinetics of serum-mediated lipopolysaccharide release and its dissociation from bacterial killing. J. Immunol. 137:1329-1335.

29. Bhakdi, S., G. Kuller, M. Muhly, S. Fromm, G. Silbert, and J. Parrisius. 1987. Formation of transmural complement pores in serum-sensitive Escherichia coli. Infect. Immun. 55:206-210.

30. Mannion, B., E. Kalatzis, J. Weiss, and P. Elsbach. 1989. Preferential binding of the neutrophil cytoplasmic granule-derived bactericidal/permeability increasing protein to target bacteria: implications and use as a means of purification. J. Immunol. 142:2807-2812. 